\title{
Evaluation of Groundwater Quality for Irrigation in Malwathu Oya Cascade-I in Anuradhapura District of Sri Lanka
}

\author{
M.K.N. Kumari*, S. Pathmarajah ${ }^{1}$, N.D.K. Dayawansa ${ }^{1}$ and K.G.S. Nirmanee ${ }^{2}$
}

Postgraduate Institute of Agriculture

University of Peradeniya

Sri Lanka

\begin{abstract}
Agro-wells (shallow agricultural wells) serve as the main source of water for irrigation of agricultural crops in dry zone of Sri Lanka. Agro-wells are extensively used by the farmers in Malwathu Oya Cascade-I, located in dry zone without proper assessment of its suitability for irrigation. Hence, this study was conducted to evaluate the quality of groundwater for irrigation in the Malwathu Oya cascade-I. Some selected vital water quality parameters (electrical conductivity, $p H$, concentration of sodium, potassium, magnesium, calcium, carbonate, bicarbonate, arsenic, lead, cadmium, nitrate nitrogen, ammonium and nitrogen) and depth to groundwater were measured once a month from June 2012 to May 2013 to represent, both pre and post monsoons in 20 selected agro-wells. Salinity, residual sodium carbonate, sodium adsorption ratio and sodium percentage were calculated using measured parameters. Point based inverse distance weighted interpolation method available in GIS was used to produce maps of spatial distribution of water quality parameters. Based on the height of water column at the end of the dry season, 20\%, 25\%, $30 \%$ and $25 \%$ of the wells had low, moderate, high and very high groundwater potential for agriculture, respectively. It was observed that almost all the chemical parameters monitored tend to concentrate towards the lower part of the cascade during the pre-monsoon period. As per the US salinity hazard diagram, 5\% of the wells had low salinity and low sodium (C1S1) while, 35\% of the wells had medium salinity and low sodium hazard (C2S1). These sources can be used for irrigation with most crops on most soils with little danger of exchangeable sodium. Sixty percent (60\%) of the water samples had high salinity, low sodium hazard (C3S1) and can be used with adequate drainage and special measures for salinity control.
\end{abstract}

Keywords: Agro-well, dry season, irrigation, Malwathu Oya cascade-I, water quality

\section{INTRODUCTION}

Inadequacy of surface water had been one of the prominent environmental constraints for the dry zone agriculture though the majority of soils of the dry zone are at acceptable fertility level. Mahaweli river diversion which was undertaken during the mid-1970s to ease the problem was not able to solve the problem completely. Due to the inadequacy of the incoming water from the wet zone to the dry zone, further attention was given for the extraction of groundwater resources through government subsidy scheme during the late

1 Department of Agricultural Engineering, Faculty of Agriculture, University of Peradeniya, Sri Lanka

2 Department of Agricultural Engineering and Soil Science, Faculty of Agriculture, Rajarata University of Sri Lanka

* Corresponding author: nadeeta@gmail.com 
1980s (Dharmasena, 1989, Karunaratne and Pathmarajah, 2003). The estimated groundwater potential of Sri Lanka is 78,000 hectare meter per annum (Panabokke and Perera, 2005). However, the geologists have recognized that the groundwater potential in hard rock region of Sri Lanka is limited for irrigation purposes, because of the low groundwater storage capacity and transmissivity of the underlying crystalline hard rockbasement (Sirimanne, 1952). Nevertheless, the introduction of the concept of agro-well (large diameter shallow well) was a revolution in dry zone farming in Sri Lanka. As a result, construction of agrowells boomed in an unplanned manner and resulted in over extraction of the shallow aquifer in the hard rock areas and resulted in drying of wells during the dry season (Shanthi de Silva, 2003). In addition to the direct rainfall obtained during the wet season, the major sources of recharge of these wells are the small tank cascade systems that are spread throughout the dry zone and the seepage water from irrigated paddy fields (Shakthivadivel et al., 1996; Panabokke, 1997). This dynamics affects not only the quantity but also the quality of the groundwater in the dry one.

Construction of wells in haphazard manner has also resulted in sitting of wells in areas where groundwater quality is unsuitable for irrigation purposes (Kendaragama, 2000; Pathmarajah and Somarathne, 2003). The chemical constituents of irrigation water can affect plant growth directly through toxicity or deficiency, or indirectly by altering plant availability of nutrients. Kendaragama (2000) has reported that presence of excessive quantities of salts in groundwater is one of the major constrains in agro-well farming in dry zone of Sri Lanka. In recent years, a significant increase in patients of Chronic Kidney Disease of unknown aetiology $(\mathrm{CKDu})$ has been observed in some parts of Sri Lanka, especially in North Central Province. According to separate studies carried out by a number of scientists, CKDu is attributed to a toxic element/s or compound/s in drinking water such as cadmium, fluoride, aluminium, toxins released by a variety of algae, pesticides etc. (Weeraratna, 2012).

A study carried out by Perera et al. (2011) on the surface water quality of one of the major cascades in the north central province called Malwathu Oya cascade-I indicated that surface water quality were better in wet flow compared to dry flow and the quality was still good enough for irrigation even in dry flow in upper and middle parts of the cascade. But the bottom of the cascade showed slight to moderate salinity condition during dry flow. It further revealed that both surface and groundwater quality of the cascade has deteriorated. The purpose of present study is to systematically monitor the groundwater quality within the Malwathu Oya cascade-I and assess its suitability for irrigation.

\section{METHODOLOGY}

\section{Location}

Malwathu Oya cascade-I is located in $\mathrm{DL}_{1 \mathrm{~b}}$ agro-ecological region of Sri Lanka and it belongs to Nuwaragam Palatha - East and Mihintale divisional secretariat areas in the Anuradhapura district. This is predominantly an agricultural area where paddy and upland crops are being cultivated. Upland crops such as long bean (Vigna unguiculata), okra (Abelmoschus esculentus), chillie (Capsicum annuum), brinjal (Solanum melongena), maize (Zea mays), big onion (Allium cepa), banana (Musa acuminate), etc. are cultivated for commercial purposes. In addition, home gardening is also popular in the area. Paddy is produced during Maha season (rainy season) and vegetables are produced almost all year round under rain-fed or irrigated conditions. 
Maha Kalaththewa, Kuda Kalaththewa, Halmillawewa, Bandialankulama, Kammalakkulama, Illuppukanniya, Nelumkanniya, Sattambikulama, Halmillewa, Palugaswewa and Thariyankulama villages of Malwathu Oya cascade-I were selected for the study. The total area of the cascade was divided into $1 \mathrm{~km}^{2}$ grids and one agro-well to represent each grid was purposely selected from aforesaid villages to assess the availability and quality of groundwater. A total of twenty wells located in uplands were selected for the study (Fig. 1).

\section{Sample collection}

Groundwater samples were obtained from the selected agro-wells once a month from June 2012 to May, 2013. The locations of the sample sites were taken by a GPS (Global Positioning System). The sampling locations are shown in Fig. 1. Before taking a sample, sampling bottles were rinsed thoroughly with the well water being sampled. After collecting the water samples, the bottles were kept air tight, labelled properly, transported to the laboratory and stored at $4^{\circ} \mathrm{C}$ until further analysis.

\section{Availability of groundwater}

Availability of groundwater in an agro-well was assessed by measuring the depth to groundwater from the surface (b) and depth of water in each well. Total depth of wells (a) was measured at the beginning of the study and depth to groundwater of each well was measured during each sampling. Availability of groundwater in agro-wells was calculated by getting the difference between these two measurements (Equation 1).

Availability of groundwater in agro-well $=\mathrm{a}-\mathrm{b}$

(Eq. 1)

\section{Chemical analysis}

The collected surface water samples were analysed for $\mathrm{pH}$, electrical conductivity (EC), calcium, magnesium, potassium, sodium, carbonate, bicarbonate, nitrate nitrogen and ammonium nitrogen at the Laboratory of Agricultural Engineering and Soil Science, Faculty of Agriculture, Rajarata University of Sri Lanka. EC and $\mathrm{pH}$ of samples were measured using multi parameter analyzer. $\mathrm{Na}^{+}, \mathrm{K}^{+}$were measured by flame photometry while $\mathrm{Ca}^{++}$and $\mathrm{Mg}^{++}$were determined using atomic absorption spectrophotometry (AAS). Carbonate and bicarbonate were measured by titration method. Nitrate nitrogen and ammonium nitrogen were determined using salicylic acid method and $4500 \mathrm{NH}_{3} \mathrm{~F}$ phenate method, respectively. In addition, samples were analysed for common heavy metals and toxic elements for plants such as arsenic (As), cadmium $(\mathrm{Cd})$ and lead $(\mathrm{Pb})$ once using AAS in the Industrial Technology Institute (ITI), Colombo. The water quality determining indices, such as Sodium Adsorption Ratio (SAR), Residual Sodium Carbonate (RSC) and Sodium Percentage ( $\mathrm{Na} \%$ ) were calculated (Equation 2, 3 and 4). Water quality parameters gathered in August and December were used to represent the pre and post monsoon periods, respectively.

$$
\begin{array}{ll}
S A R= & \frac{\mathrm{Na}^{+}}{\sqrt{\frac{\mathrm{Ca}{ }^{2+}+\mathrm{Mg}^{2+}}{2}}} \\
\mathrm{Na}^{+} & \text {Concentration of sodium (meq/L) } \\
\mathrm{Ca}^{2+} & \text { Concentration of calcium (meq/L) } \\
\mathrm{Mg}^{2+} & \text { Concentration of magnesium (meq/L) }
\end{array}
$$


$\mathrm{RSC}=\left(\mathrm{HCO}_{3}^{-}+\mathrm{CO}_{3}^{2-}\right)-\left(\mathrm{Ca}^{2+}+\mathrm{Mg}^{2+}\right)$

$\mathrm{HCO}^{3-}$ Concentration of bicarbonate $(\mathrm{meq} / \mathrm{L})$

$\mathrm{CO}^{3-} \quad$ Concentration of carbonate $(\mathrm{meq} / \mathrm{L})$

$\mathrm{Ca}^{2+} \quad$ Concentration of calcium $(\mathrm{meq} / \mathrm{L})$

$\mathrm{Mg}^{2+} \quad$ Concentration of magnesium (meq/L)

$\mathrm{Na} \%=\frac{\left(\mathrm{Na}^{+}\right) \times 100}{\left(\mathrm{Ca}^{2+}+\mathrm{Mg}^{2+}+\mathrm{Na}^{+}+\mathrm{K}^{+}\right)}$

$\mathrm{Ca}^{2+} \quad$ Concentration of calcium $(\mathrm{meq} / \mathrm{L})$

$\mathrm{Mg}^{2+} \quad$ Concentration of magnesium (meq/L)

$\mathrm{Na}^{+} \quad$ Concentration of sodium (meq/L)

$\mathrm{K}^{+} \quad$ Concentration of potassium $(\mathrm{meq} / \mathrm{L})$

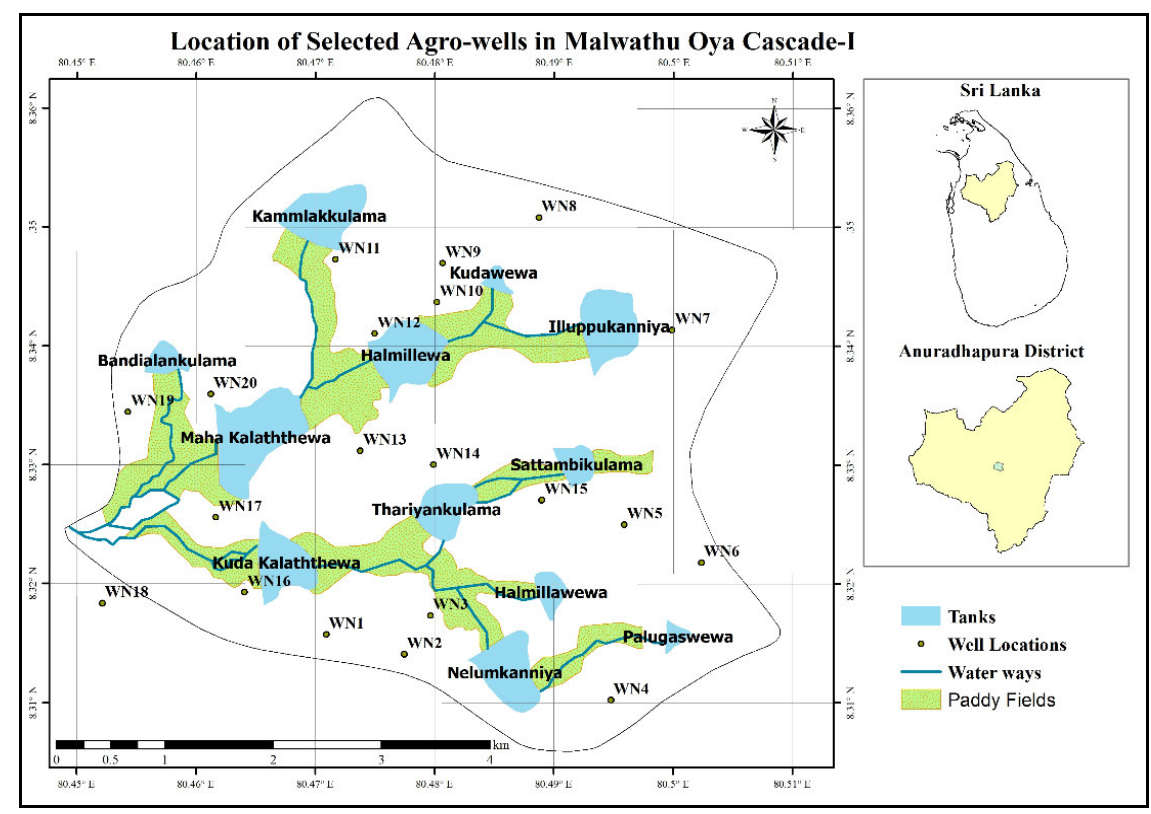

Fig. 1. Location of selected agro-wells in Malwathu Oya cascade-I

\section{Mapping of spatial variability of groundwater}

Once the input data was imported as a point layer in to ArcGIS a geo-database was created to generate the spatial distribution maps of selected water quality parameters. Considering the past research (Naoum and Tsanis, 2004; Tikle et al. 2012; Sluiter, 2009), point based IDW interpolation method was used to produce maps showing spatial distribution of water quality parameters.

Combination of EC (salinity hazard) and SAR (sodium hazard) as proposed in US salinity diagram (Wilcox, 1955) was used to classify the groundwater for irrigation. Two sample Ttest and ANOVA were carried out to compare the water quality parameters during pre (August) and post (December) monsoon period and between different land use types using Statistical Analysis System (SAS) software. 


\section{RESULTS AND DISCUSSION}

\section{Seasonal groundwater availability}

Monthly average groundwater availability of the agro-wells in the study area varied from 1.1 $\mathrm{m}$ to $6.7 \mathrm{~m}$. September recorded the lowest and December recorded the highest groundwater availability. July, August and September water heights were very low and with the onset of rainfall it increased in all the wells. Maximum water height was recorded in December. Based on the results of two sample T-test, significant difference in groundwater availability between two situations (pre and post monsoon) was observed. Higher water height could be observed during post monsoon due to rainfall recharge (Fig. 2).

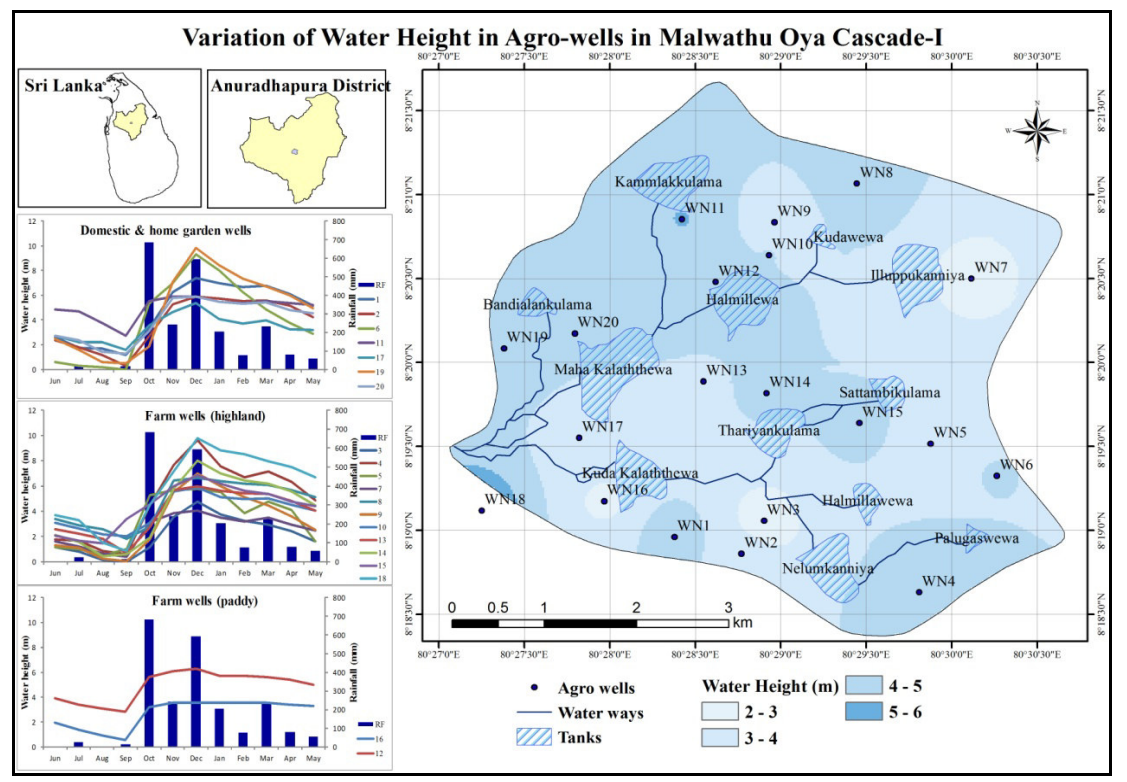

Fig. 2. Variation of water height in agro-wells in Malwathu Oya cascade-I

The agro-wells are grouped into four classes based on the depth water available at the end of dry season as low $(0.0-0.5 \mathrm{~m})$, moderate $(0.5-1.0 \mathrm{~m})$, high $(1.0-2.0 \mathrm{~m})$ and very high $(>2.0$ $\mathrm{m})$ groundwater potential (Perera et al., 2002). Based on the height of water column at the end of the dry season (August, 2012), 20\% of the selected agro-wells had low groundwater potential, $25 \%$ had moderate groundwater potential, $30 \%$ had high groundwater potential and rest of the selected agro-wells had very high groundwater potential for agriculture (Fig. 3). 


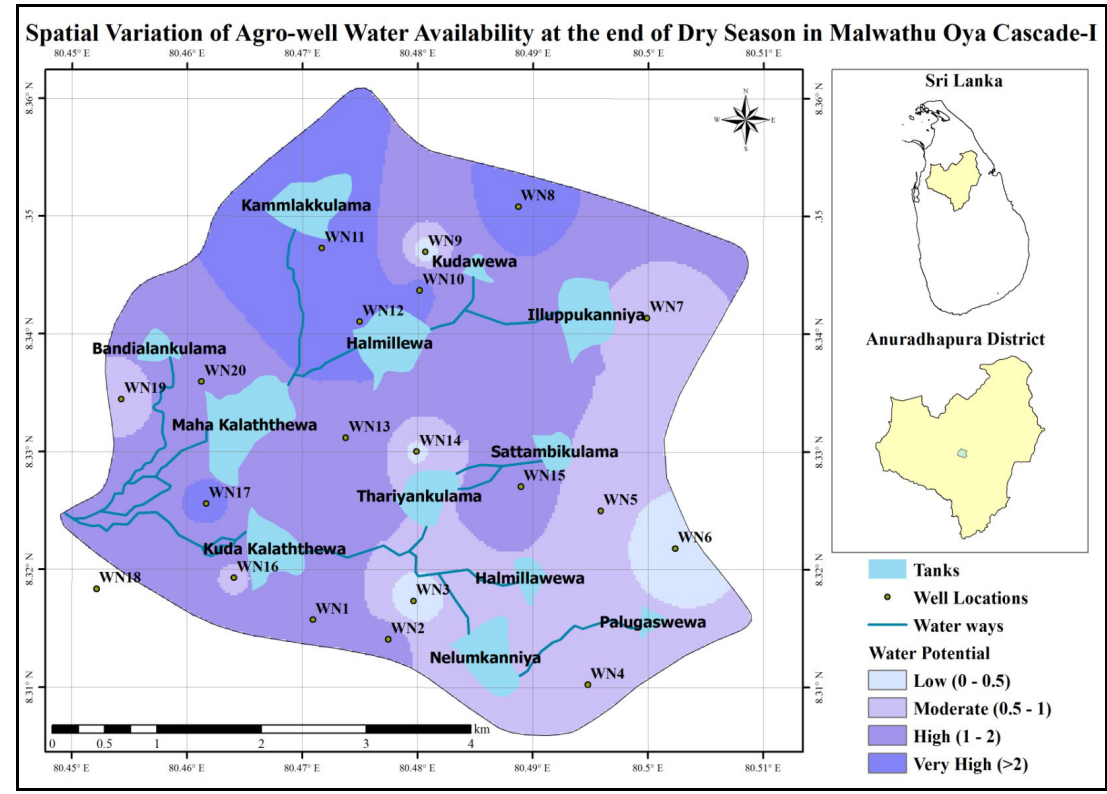

Fig. 3. Spatial variation of water availability in agro-wells at the end of dry season in Malwathu Oya cascade-I

\section{Physio-chemical parameters of groundwater in Malwathu Oya Cascade-I}

\section{pH in groundwater}

The $\mathrm{pH}$ values of selected agro-wells in Malwathu Oya cascade-I varied between 7.2 and 8.4 in pre monsoon period, which indicates the alkaline nature of groundwater in the study area. Among those, $60 \%$ of the wells had $\mathrm{pH}$ between 7.5 and 8.0 and well number 16 recorded the highest $\mathrm{pH}$ of 8.1 . High $\mathrm{pH}$ values were recorded in dry months in all land use patterns and low $\mathrm{pH}$ values were recorded with the onset of rainfall (Fig. 4). During wet season, rainfall combines with carbon dioxide in the atmosphere and influences the water towards acidity (Idoko and Oklo, 2012). Since the groundwater is recharged basically from rainfall, it could be the probable reason for reduction of $\mathrm{pH}$. According to the results of two sample Ttest, a significant difference between two periods (pre and post monsoon) was not observed. Based on the $\mathrm{pH}$ values, all the wells were suitable for irrigation throughout the year. 


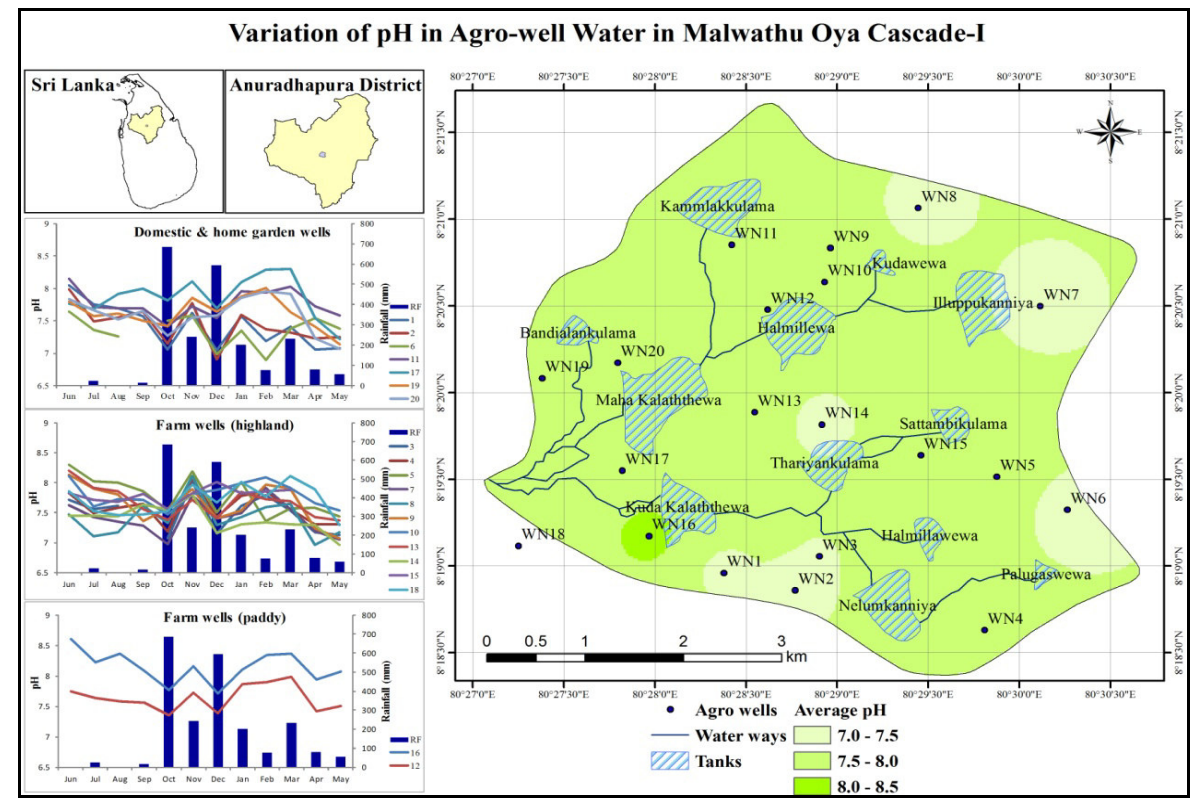

Fig. 4. Variation of average pH in Malwathu Oya cascade-I

\section{Nitrate nitrogen concentration in groundwater}

According to Ayers and Westcot (1985), restriction of nitrate nitrogen content for irrigation water can be categorized as $0-5 \mathrm{mg} / \mathrm{L}$ (no restriction), $5-30 \mathrm{mg} / \mathrm{L}$ (slight to moderate) and $>30 \mathrm{mg} / \mathrm{L}$ (severe). Eighty five (85\%) of the wells had nitrate nitrogen between $0-5 \mathrm{mg} / \mathrm{L}$, while rest of the wells had $5-30 \mathrm{mg} / \mathrm{L}$ during pre-monsoon period whereas during post monsoon period, nitrate nitrogen concentration has increased in all the wells. Nitrate nitrogen was comparatively higher in well number 04,14 and 18 where intensive agriculture is practiced and possibly due to washing off of fertilizer from the crop fields and livestock effluent (Fig. 5). The reasons for higher nitrate nitrogen content may be addition of livestock manure and waste, excess fertilizer application, and rainfall leaching. The most probable cause for the high concentration of $\mathrm{NO}_{3}{ }^{-} \mathrm{N}$ concentration during wet season could be the excess fertilizer leaching to the shallow groundwater. Gunasekaram (1983) and Mageswaran and Mahalingam (1983) have reported that the nitrate level increase in groundwater due to leaching of excess fertilizer to the shallow groundwater table. An extensive study conducted recently by Mikunthan et al. (2012) confirms the above finding. However, significant difference between two situations (pre and post monsoon) of $\mathrm{NO}_{3}{ }^{-} \mathrm{N}$ concentration was not observed in Malwathu Oya cascade-I. Compared to domestic and farm wells (paddy), $\mathrm{NO}_{3}{ }^{-} \mathrm{N}$ concentration was high in farm wells (highland). Based on ANOVA, significant differences could be observed among the three land use types $(p<0.001)$ and according to mean separation, farm wells (highland) recorded the highest mean value $(\overline{\mathrm{x}}=6.43)$. This was supported by Mikunthan et al. (2012) that high $\mathrm{NO}_{3}{ }^{-} \mathrm{N}$ content was observed in highland crops followed by banana and paddy in Jaffna peninsula. It suggests that proper fertilizer management is essential when irrigating with the water to avoid any adverse effect of excessive nitrogen. 


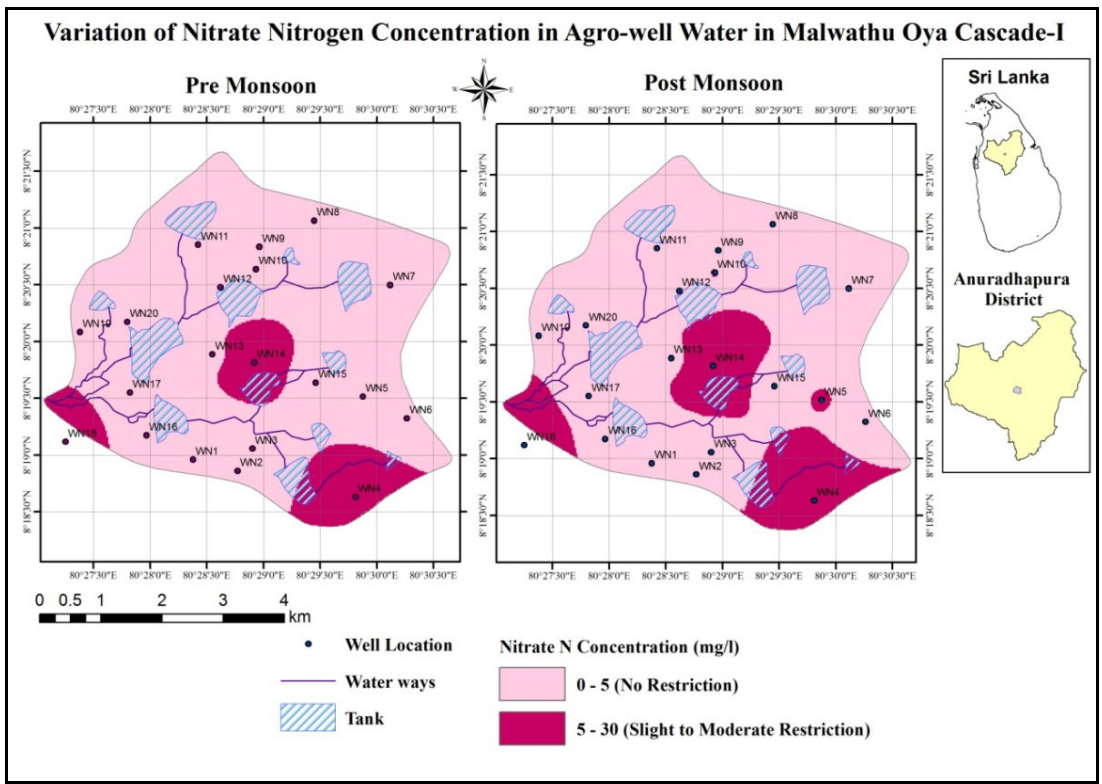

Fig. 5. Variation of average nitrate nitrogen concentration in Malwathu Oya cascade-I

\section{Ammonium nitrogen concentration in groundwater}

Ninety percent $(90 \%)$ of the wells had ammonium nitrogen concentration between 0 to 5 $\mathrm{mg} / \mathrm{L}$ and rest of the wells (well no 4 and 18 ) recorded $15-20 \mathrm{mg} / \mathrm{L}$ during pre-monsoon period (Fig. 6). With the onset of monsoon ammonium nitrogen content has increased in almost all the wells in the cascade and well number 04 and 18 recorded the highest. Although both 04 and 18 are constructed wells, there is a high potential to contaminate the groundwater in these wells with livestock effluents due to nearby location of cattle sheds to the well and excessive application of fertilizer to crop fields. Ammonium nitrogen is found in groundwater naturally as a result of anaerobic decomposition of organic material. It is also commonly found in groundwater due to anthropogenic activities, primarily due to leaching from fertilizers, organic waste disposal or leaking sewage systems (Lindenbaum, 2012). Based on the results of two sample T-test, a significant difference between ammonium nitrogen concentration under two situations (pre and post monsoon) was not observed. 


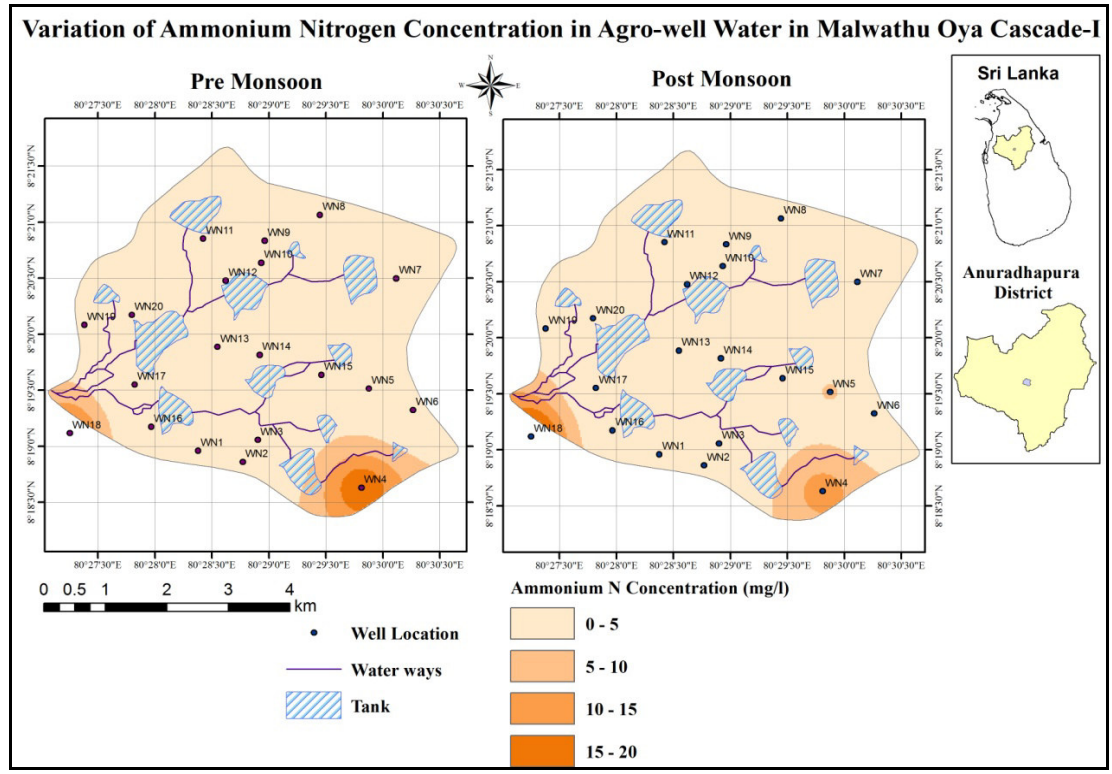

Fig. 6. Spatial variation of ammonium nitrogen concentration during pre and post monsoon period in Malwathu Oya cascade-I

\section{Heavy metals in groundwater}

According to the results, arsenic (As) was detected in well number 6 and 16 in $0.001 \mathrm{mg} / \mathrm{L}$ while it was not found in the rest of the wells. Based on Ayers and Westcot (1985), maximum allowable limit of As in irrigation water is $0.1 \mathrm{mg} / \mathrm{L}$. Hence the water is suitable for irrigation. Cadmium $(\mathrm{Cd})$ and lead $(\mathrm{Pb})$ were not detected in all the wells.

\section{Assessment of hazards}

\section{Salinity}

Water salinity is usually measured by the TDS or the EC. EC is a good measurement of salinity when using groundwater for irrigation. The primary effect of high EC in irrigation water on crop productivity is the inability of the plant to compete with ions in the soil solution for water which leads to less water availability to plants (Tatawat and Chandel, 2008). Classification of groundwater based on salinity hazard was done according to the recommendation of Wilcox (1955). Accordingly, it was grouped as Excellent (100$250 \mu \mathrm{S} / \mathrm{cm})$, Good $(250-750 \mu \mathrm{S} / \mathrm{cm})$, Doubtful $(750-2250 \mu \mathrm{S} / \mathrm{cm})$ and Unsuitable $(>2250 \mu \mathrm{S} / \mathrm{cm})$. Based on EC, $5 \%$ of the wells had excellent, $35 \%$ of the wells had good quality water and $60 \%$ of the wells had doubtful quality for irrigation and major portion of the cascade falls into the category of 'doubtful' (Fig. 7). Special management for salinity control may be required. 


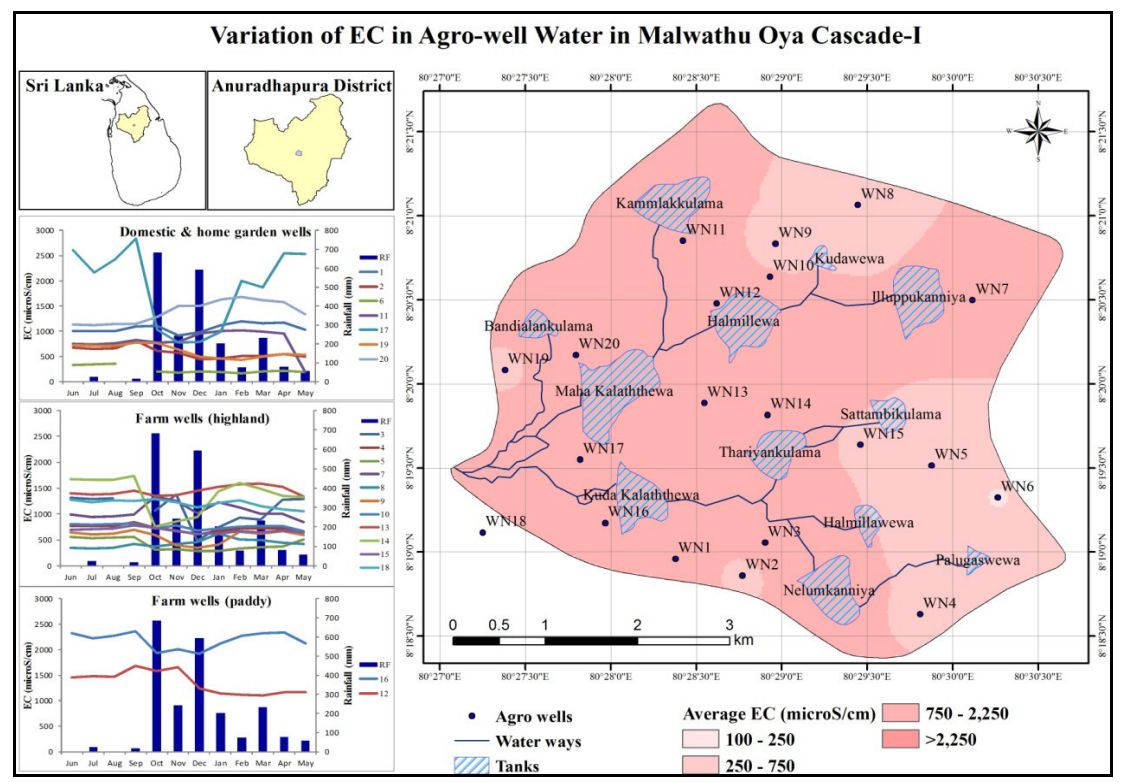

Fig. 7. Variation of average salinity in Malwathu Oya cascade-I

\section{Sodium hazard}

\section{Sodium percentage}

Irrigation water containing large amounts of sodium is of special concern due to sodium's effects on the soil and poses a sodium hazard. Excess sodium in water produces undesirable effects of changing soil properties and reducing soil permeability. Based on average sodium percentage $35 \%$ of the wells in the cascade had excellent irrigation water quality, $60 \%$ had good irrigation water quality and 5\% had permissible irrigation water quality. As shown in Fig. 8 similar fluctuation pattern was observed in all three land use types and $\mathrm{Na} \%$ was high in farm wells (paddy) compared to other two land use types (Farm wells-upland, domestic \& home garden wells). 


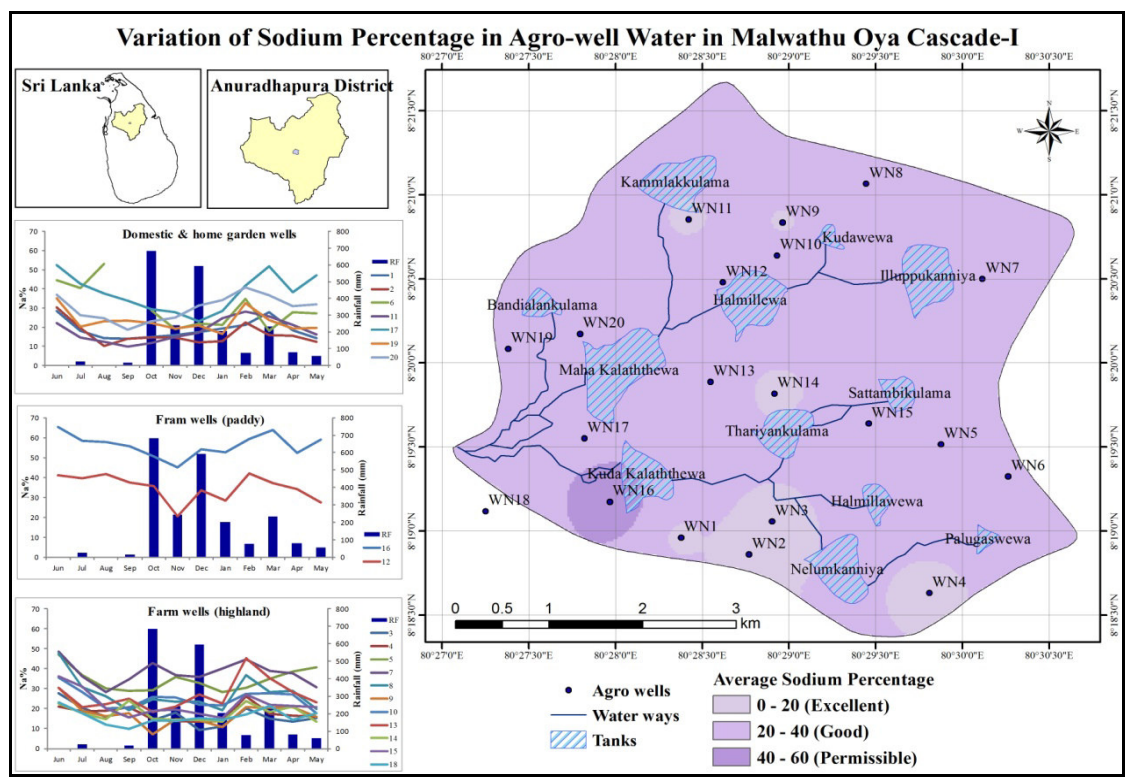

Fig. 8. Variation of average sodium percentage in Malwathu Oya cascade-I

\section{Sodium adsorption ratio (SAR)}

Sodium hazard is also usually expressed in terms of the sodium adsorption ratio (SAR). SAR values of each sample were calculated by the formula proposed by Richards (1954). Groundwater could be also classified based on SAR as excellent (0-10), good (10-18), doubtful (18-26) and unsuitable (>26). Almost all the wells had SAR between 0- 4 except well number 6,16 and 17 in dry season, whereas $95 \%$ of the wells had SAR below 4 and 5\% of the wells had SAR between 4 and 8 in post monsoon (Fig. 9). According to SAR, groundwater in the study area is suitable for irrigation with no danger of exchangeable sodium. 


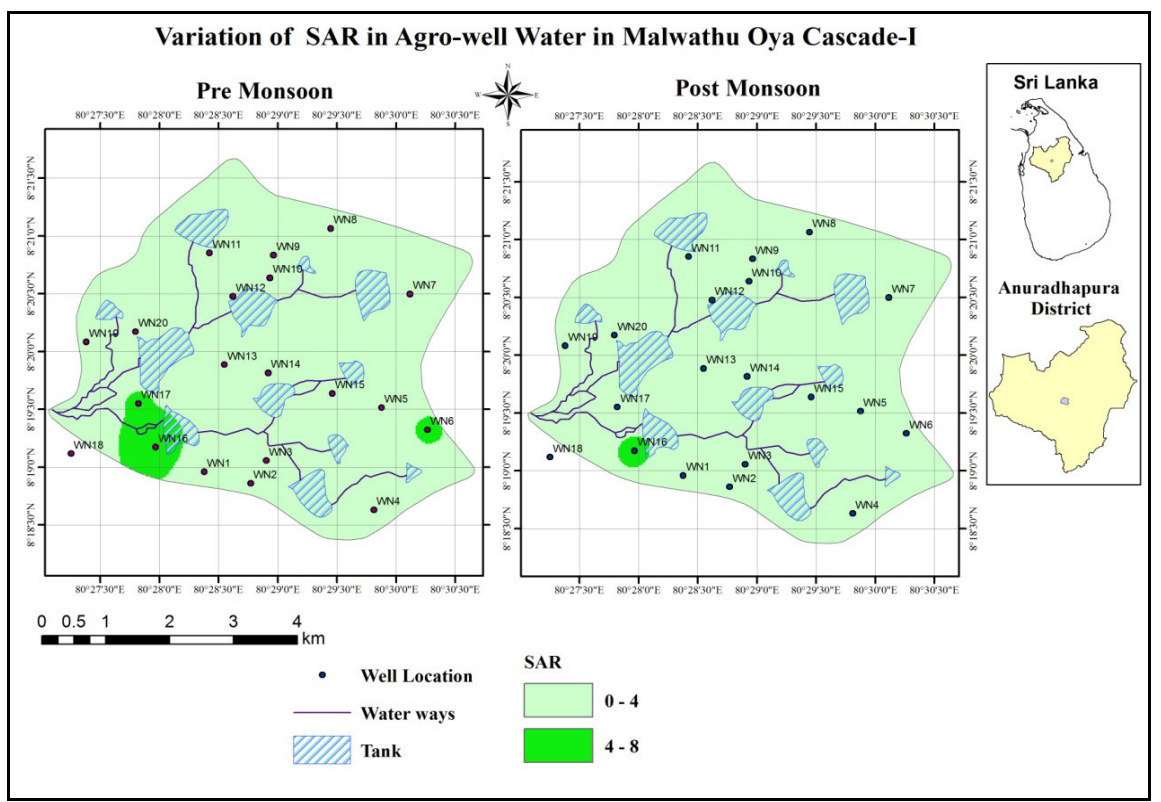

Fig. 9. Variation of SAR during pre and post monsoon period in Malwathu Oya cascade-I

\section{Bicarbonate hazard}

\section{Residual sodium carbonate (RSC)}

Bicarbonate hazard is usually expressed in terms of RSC (Residual Sodium Carbonate). The classification of water quality for irrigation on the basis of RSC was proposed by Eaton (1950). Residual carbonate level less than $1.25 \mathrm{meq} / \mathrm{L}$ is considered as safe, while water with $1.25-2.5 \mathrm{meq} / \mathrm{L}$ is within the marginal range. Based on average values, RSC in pre and post monsoon all the wells had good quality water. However, based on the results of two sample T-test, a significant difference between two situations (pre and post monsoon) of RSC was observed.

\section{Classification of groundwater}

The US salinity diagram (Richard, 1954) was used to classify the groundwater for irrigation. Combination between EC (salinity hazard) and SAR (sodium hazard) had been used in US salinity diagram. Out of the selected wells, $5 \%$ fall under C1S1, indicating low salinity and low sodium and $35 \%$ fall under $\mathrm{C} 2 \mathrm{~S} 1$, indicating medium salinity and low sodium hazard. Water belonging to this class is suitable for most plants provided that moderate amount of leaching takes place or for plants with moderate salinity tolerance without considerable practices for salinity control (Shaki and Adeloye, 2006). Sixty percent of the samples fall in to $\mathrm{C} 3 \mathrm{~S} 1$ category with high salinity and low sodium. These wells can be used on soils with adequate drainage. Even with adequate drainage, special management for salinity control may be required and plants with good salt tolerance should be selected.

Based on all water quality parameters, suitability of groundwater for irrigation is shown in Fig. 10. During pre-monsoon period $35 \%$ and $65 \%$ of the well water was categorized as good 
and doubtful for irrigation, respectively while $45 \%$ and $55 \%$ of the wells fall in to good and doubtful category for irrigation during post monsoon period, respectively. In areas where irrigation water quality is doubtful, there is a risk of yield reduction for most commonly cultivated crops like chilli, brinjal, long bean and okra.

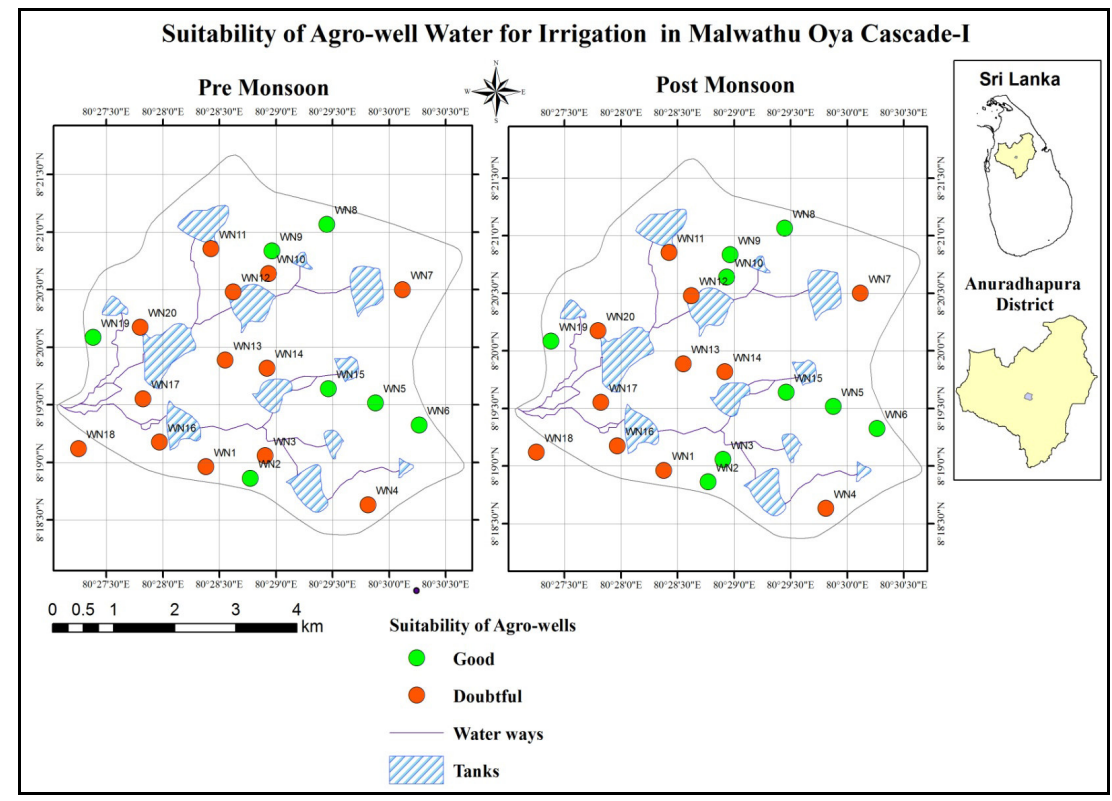

Fig. 10. Suitability of groundwater for irrigation in Malwathu Oya cascade-I

\section{CONCLUSIONS}

Malwathu Oya Cascade-I has a good groundwater potential for agriculture. Based on the height of water column at the end of the dry season (August 2012), 20\% of the selected agrowells had low groundwater potential, $25 \%$ had moderate groundwater potential, $30 \%$ had high groundwater potential and rest of the selected agro-wells had very high groundwater potential for agriculture.

It was observed that almost all the chemical parameters monitored except nitrate and ammonium tends to concentrate towards the lower part of the cascade during the premonsoon period. However, the concentration is reduced substantially during the monsoon. Nitrate tends to be high in areas with agricultural activities; however, the effect of land use on nitrate concentration is not clear. Site specific fertilizer recommendation based on the availability of nitrate in groundwater may be required to prevent any effect of excessive nitrate.

As per the US salinity hazard diagram, $5 \%$ of the wells had low salinity and low sodium hazard (C1S1) while $35 \%$ of wells had medium salinity and low sodium hazard (C2S1). These wells can be used for irrigation with most crops on most soils with little danger of exchangeable sodium. Sixty percent $(60 \%)$ of the wells had high salinity and low sodium hazard $(\mathrm{C} 3 \mathrm{~S} 1)$. This water can be used for irrigation with adequate drainage and special measures for salinity control. 
Based on all the water quality parameters, $35 \%$ and $65 \%$ of the well water was categorized as good and doubtful for irrigation during pre-monsoon, respectively, while $45 \%$ and $55 \%$ of the wells fall in to good and doubtful category for irrigation during post monsoon period, respectively. In areas where irrigation quality is doubtful, there is a risk of yield reduction for most commonly cultivated crops like chilli, brinjal, long bean and okra.

\section{REFERENCES}

Ayres, R.S. and Westcot, D.W. (1985). Water quality for agriculture. FAO irrigation and drainage paper no. 29. Food and agriculture organization of the United Nations, Rome.

De Silva, S. (2003). Regulation of shallow groundwater resources in hard rock areas of Sri Lanka. In: Pathmarajah, S. (Ed.). Proceedings of the symposium on the use of groundwater for agriculture in Sri Lanka, 30 September 2002. Peradeniya, Sri Lanka, pp. 42 - 52.

Dharmasena, P.B. (1989). Optimum utilization of the storage in village tanks. Tropical Agriculturist. 145, 01-09.

Eaton, F.M. (1950). Significance of carbonates in irrigation waters. Soil Science. 69, 123133.

Gunasekaram, T. (1983). Groundwater contamination and studies in limestone aquifer of Jaffna, Sri Lanka. [on line]. [Accessed on 03/07/2014]. Available at http://www.iwmi.cgiar.org/Publications/Books/PDF/jaffna_report-1.pdf

Idoko, O.M. and Oklo, A. (2012). Seasonal variation in physico-chemical characteristics of rural groundwater of Benue state, Nigeria. Journal of Asian Scientific Research. 2(10), 574586.

Karunaratne, A.D.M. and S. Pathmarajah. (2003). Groundwater development through introduction of agro-wells and micro-irrigation in Sri Lanka. In: Pathmarajah, S. (Ed.). Proceedings of the symposium on the use of groundwater for agriculture in Sri Lanka, 30 September 2002. Peradeniya, Sri Lanka. pp. 29 - 41.

Kendaragama, K.M.A. (2000). Quality of agro-well water in the dry zone- a case study in Anuradhapura district. Journal of the soil science society of Sri Lanka. 12, 26-33.

Lindenbaum, L. (2012). Identification of sources of ammonium in groundwater using stable nitrogen and boron isotopes in Nam Du, Hanoi. Department of Geology, Lund University.

Mageswaran, R. and Mahalingam, R. (1983). Nitrate nitrogen content of well water from selected areas in the Jaffna peninsula. Journal of National Science Council, Sri Lanka. 2(1), 269-275.

Mikunthan, T., Vithange, M., Pathmarajah, S., Arasalingam, S., Ariyaratne, R. and Manthrithilake, H. (2012). Hydro geochemical characterization of Jaffna's aquifer system in Sri Lanka. International Water Management Institute. 27-56.

Naoum, S. and Tsanis, I.K. (2004). A multiple linear regression GIS module using spatial variables to model orographic rainfall, Journal of Hydroinformatics. 6, 39-56. 
Panabokke, C.R. (1997). Groundwater conditions in Sri Lanka. National Science Foundation of Sri Lanka. pp. 19-26.

Panabokke, C.R. and Perera, A.P.G.R.L. (2005). Groundwater resources of Sri Lanka. Water Resources Board, Sri Lanka. pp. 3-11.

Pathmarajah, S. and Somarathne, H.M. (2003). Reasons for abandoning agro-wells (large diameter wells): An empirical study. Sri Lankan Journal of Agricultural Science. 40, 10-22.

Perera, A.P.G.R.L., Wijekoon, D.V.K and Senevirathna, A.A.A.K.K. (2002). Water quality of agro-wells in the Anuradhapura district. Symposium proceedings on the use of groundwater for agriculture in Sri Lanka, PGIA, University of Peradeniya, Sri Lanka. pp. 7484.

Perera, K.T., Gunarathna, M.H.J.P. and Ranagalage, M.M. (2011). Evaluation of surface water resources in Malwathu Oya Cascade-I. Undergraduate research symposium proceedings, Faculty of Agriculture, Rajarata University of Sri Lanka. pp. 52.

Richard, L.A. (1954). Diagnosis and improvement of saline and alkali soils. Agric. Handbook 60, U.S. Department of Agriculture, Washington.

Sakthivadivel, R., Fernando, N., Panabokke, C.R. and Wijayaratne, C.M. (1996). Nature of small tank cascade systems and a framework for rehabilitation of tanks within them, Colombo, Sri Lanka. International Irrigation Management Institute (IIMI). 4, 54. (IIMI Country Paper, Sri Lanka No. 13).

Shaki, A.A. and Adeloye, A.J. (2006). Evaluation of quantity and quality of irrigation water at Gadowa irrigation project in Murzuq basin, southwest Libya. Journal of Agricultural Water Management. 84, 193-201.

Sirimanne, C.H.L. (1952). Geology for water supply Ceylon. As. Advmt. Sci. 8th Annual Session. 2, 87-118.

Sluiter, R. (2009). Interpolation methods for climate data literature review. [on line].

[Accessed on 08/05/2014]. Available at http://www.knmi.nl/bibliotheek/knmipubIR/IR200904.pdf.

Tatawat, R.K. and Chandel, C.P.S. (2008). Quality of groundwater of Jaipar city, Rajasthan (India) and its suitability for domestic and irrigation purpose. Applied Ecology and Environmental Research. 6(2), 79-88.

Tikle, S., Saboori, M.J. and Sankpal, R. (2012). Spatial distribution of groundwater quality in some selected parts of Pune city, Maharashtra, India using GIS, Current World Environment. $7(2), 281-286$.

Weeraratna, C.S. (2012). Chronic renal failure: Thousands are affected. The Island, March 19, 2012.

Wilcox. L.V. (1955). Classification and use of irrigation waters. U.S. Dept. Agric. Circular 969, Department of Agriculture, Washington. 